\title{
Factors of Sufi Ideology Influence on the Formation of the Tatar Hand-Written Book Traditions
}

\author{
Firdaus G. Vagapova ${ }^{1} \&$ Larisa N. Donina ${ }^{2}$ \\ ${ }^{1}$ Kazan (Volga Region) Federal University, Kazan, Russia \\ ${ }^{2}$ Institute of History named after Sh. Mardzhani of Academy of Sciences of the Republic of Tatarstan, Kazan, \\ Russia \\ Correspondence: Firdaus G. Vagapova, Kazan (Volga Region) Federal University, 420008, Kazan, \\ Kremlyovskaya Street, 18, Russia. E-mail: vagap.art@mail.ru
}

Received: June 15, 2015 Accepted: June 24, 2015 Online Published: June 30, 2015

doi:10.5539/jsd.v8n7p147 URL: http://dx.doi.org/10.5539/jsd.v8n7p147

\begin{abstract}
The timeliness of the research is determined by the following: in the contemporary world scholars studying the national traditional cultures and awareness of the importance of the book art in its historical development are some of the basic conditions for solving the problems of not only preservation of spiritual and material culture monuments, but the study of the cultures genesis, identification of opportunities for their further development. The paper aims to evince the importance and influence of Sufi ideology on the formation of book art traditions. The study of the problem is based on the classical methods of different sciences: history, culturology, art studies, which help to create a holistic picture of the development of the book art in the Tatar culture. The paper reveals the peculiarities of the development of Tatar hand-written book art, including the following factors brought by Sufism ideology: the absence of any graphic elements, key role of symbols of the universe model, the symbols of color and compositional text distribution on the page. Results and study findings can be used during the preparation of special courses and programs "History of culture and religion", "Cult of the peoples of Tatarstan", "History of World Culture".
\end{abstract}

Keywords: Sufism, asceticism, mysticism, Tatar hand-written book

\section{Introduction}

The book is an important part of the spiritual culture of the nation. It is a monument of creative thought, it bridges the present and the past, opening the way for new discoveries. The centuries-old history of the Tatar people shows that learning has occupied a special place in its rich spiritual culture, thus giving rise to the reverent attitude to the book as a source of knowledge. The book instills aesthetic qualities in a reader, so calligraphers of ancient tomes devoted special attention to its artistic look.

Tatar hand-written book imbibed the traditions of the Eastern Muslim, mostly Central Asian art of book. Features of oriental influence could be seen in the design of the book block, functionality of its components, materials and technology of bookbinding. However, the artistic features of the Tatar manuscript book are different from eastern counterparts: it is characterized by the absence of graphic elements. According to researcher L. Dmitrieva "there were no artistically designed Arabic written manuscripts in the Volga-Ural region" (Dmitrieva, 1987).

Objective historic conditions influenced the formation of the artistic decoration traditions of Tatar hand-written book. Sufism, a mystical ascetic dimension of the Islam, played the fundamental role in this process. Sufism is characterized by the cult of poverty which resulted in a strongly marked simplicity of the book. Ornamental pattern introduced to the design of the first broadside of the book - Unvan, which was specific to the books of the Arab-Muslim world, appeared in the Tatar book culture only in the middle of the XIX century. In the early periods Tatar calligraphers used only implied forms of placing the text on page, such as rhythm, texture of the material and symbols, the figurability of the Arabic script was used as a means of book design.

Consequently, specific distinctive features were developed in the Tatar hand-written book culture. 


\section{Methodological Framework}

\subsection{Objectives of the Study}

The following tasks were tackled during the research:

- To study the historiography of Sufism formation in the Volga region in the period from the $10^{\text {th }}$ to the beginning of the $19^{\text {th }}$ centuries;

- To specify historical situation against the background of which the Sufism ideology formed in the Volga region;

- To examine the aspects of Sufism which directly and indirectly influenced the artistic and graphic content of the Tatar book.

\subsection{Theoretical and Methodological Basis of the Study}

This paper is written at the confluence of various sciences - art studies, history and culturology and is based on a holistic systemic approach to the problem of identifying traditions and peculiarities of Tatar hand-written book design. Classical comparative historical method, including synchronic and diachronic analysis, is of priority in the paper. Art analysis is based on the perception of Tatar books as an artistic and graphic pattern. The paper also uses general scientific and culturological methods and approaches: genetic, allowing to make diachronic analysis and follow the book art formation process; comparative, implying comparative historical analysis of the book in the Tatar culture of $15^{\text {th }}-19^{\text {th }}$ centuries.

\subsection{The Basis of the Study}

The basis of the study is the collections of manuscripts kept in the Department of Manuscripts and Rare Books of N.I. Lobachevsky Scientific Library of Kazan Federal University (DMRB of N.I. Lobachevsky SL KFU), the Center for Written and Musical Heritage of G. Ibragimov Institute of Language Literature and Arts of the Academy of Sciences of the Republic of Tatarstan (CWMH of G.Ibragimov ILLA of AS RT), the Department of Rare Books and Manuscripts of the National Library of the Republic of Tatarstan (DRBM of NL RT), the National Museum of the Republic of Tatarstan (RT HM), the National Archives of the Republic of Tatarstan (NA RT ), the Graphic Art Department of the State Museum of Fine Arts of the Republic of Tatarstan (SMFA RT) and private collections.

\section{Results}

Adoption of Islam by the state of Volga Bulgaria in 922 contributed to the establishment of close contacts with the countries of the Middle East and Central Asia. Abul Hamid Ali Ibn Idris al-Bulgari, Suleiman ibn Daud al-Saksina, Burhan al-Din al-Bulgari studied in the largest schools of Bukhara and Nishapur in Central Asia, brothers Tadzhad-Din and Hassan Ibn Yunus al-Bulgari as well as many others received Islamic higher education in Iraq (Ocherki, 2000). Returning home, they wrote works on religious subjects (commentary on the Koran, fiqh books, hadith collections), worked on astronomy, medicine and other sciences (Ibrahim, Sultanov \& Yuzeev, 2002).

Relationship between Bolgar scientists and countries of the Muslim East, and especially of Central Asia were not ceased in the next periods of the state development. In 1236, after the invasion of the Mongols Volga Bulgaria, though preserving the status of an autonomous state becomes part of the Golden Horde. From the middle of the $15^{\text {th }}$ century, after the collapse of the Golden Horde when it resolved into separate khanates the formation of the Tatar people culture again goes on in the context of an independent state and Kazan becomes its center. Kazan Khanate had a high level of material and spiritual culture. It had active trade and diplomatic relations with the countries of the Arab Muslim East and Central Asia. Tatar scholars and clergymen were educated in Bukhara, Turkey, Dagestan.

Therefore, representatives of the Bolgar-Tatar clergy and scholars maintained regular contacts with the Central Asian cities, where they perfected their education, and here, through their teachers, they were imbued with the ideas of Sufism. M. Kemper suggests that "since the time of the Golden Horde local Sufis were connected with the Central Asian mystic tradition" (Kemper, 2008).

Sufism, which arose under the Umayyads in the $8^{\text {th }}-10^{\text {th }}$ centuries, represented the movement of ascetic-hermits (Dervish). Every person who wanted to devote oneself to dervish lifestyle chose a mentor (Sheikh), which led to the formalization of the spiritual guidance statute that was in force within established communities. Later isolated Sufi mosques united into brotherhoods (tariqahs), led by mentors. The largest Sunni brotherhoods: Qadiriya, Maulyaviya, Yasaviya, Naqshbandiyya, Haydariya were called after their sheikh.

Domestic and foreign researchers (Amirhanov, 1993; Yuzeev 2001, 2007; Kemper, 2008; Allen J. Frank, 1996) 
suggest that Sufism in the Volga region was influenced by Yasaviya Tariqah (Yasawa) since the late Middle Ages to the $18^{\text {th }}$ century. Ahmed Yasawi - a mystic poet, one of the leaders of Sufism, the founder of the Sufi brotherhood Yasaviya, was born in 1091 in Turkestan (Islam, 2004). Yasawi and his followers preached the idea of overwhelming desire to cognize God, detachment from all mundane problems. The influence of Yasaviya brotherhood traditions is traced in the works of Tatar Sufi poets of $16^{\text {th }}, 17^{\text {th }}, 18^{\text {th }}$ centuries. For example, one of the poems of the outstanding Tatar poet and religious leader, head of Kazan Khanate muslims (Seid) Kul Sharif (? -1552) (Kul Shərif, 1997), is dedicated to the son of Central Asian Sufi poet Suleiman Bakyrgani, whose works were wide-spread among the Tatars till the $20^{\text {th }}$ century. Suleiman Bakyrgani was a student of Ahmad Yasawi (M. Kemper, 2008). Khikmets of the famous Muslim Sufi poet Mawla Kolyi, who lived in Kazan in about 1080 (M. Kemper, 2008), also have some features of Yasavi poetry.

Naqshbandiyya Tariqah, named after Bahaaddin Naqshbandi, had become the most common and wide-spread in Central Asia by the $15^{\text {th }}$ century (Islam, 2004). The middle of the $16^{\text {th }}$ century was a difficult period in the history of the Tatar people. It was a time of the statehood elimination, attacks on the fundamentals of spiritual life, attempts to eradicate the Muslim religion, which resulted in the forced conversion of the Muslim Tatars into Christianity. But Bolgar-Tatar scholars still maintain contact with the clergy from Central Asia. Since the end of the $17^{\text {th }}$ century "again Bolgar scientists increasingly travel to Bukhara. Here they come under the influence of Naqshbandiyya, which forces out or assimilates with Yasaviya" (Kemper, 2008). M. Kemper notes that "it is obvious that in the second half of the $18^{\text {th }}$ century Naqshbandiyya became a leading brotherhood in Tatarstan" (Kemper, 2008). Distinguished sheikhs Habiballah-Ishan al-Oruva, Abdrrahim al-Bulgari (aka Utyz Imyani), sheikhs Ubaydallah Djagfar bin al-Kizlyavi and Tajeddine Yalchigul bin al-Bulgari and others were representatives of Naqshbandiyya Tariqah culture in the Volga region. All of them embraced the Naqshbandiyya doctrine studying in Central Asia, or through their teachers.

Therefore, two Sufi Tariqahs spread in the Volga region: Yasaviya and Naqshbandiyya differing in some key issues. The sheikhs of the Yasaviya brotherhood favored "Loud Remembrance of God" in which words "la ilaha illa illallah" are said aloud (Algar Hamid, 1976). Such remembrance of God is defined as "dhikr Jahra", whereby they sometimes called Yasaviya "dzhahriya"(Kemper, 2008). Representatives of Naqshbandiyya were different as they practiced "quiet remembrance of God." Besides, Naqshbandiyya is characterized by the recognition of dualism of mystical knowledge in which "mystic will never experience unity with God, but at the apogee of the mystical meditation he sees Oneness of God and becomes convinced of his versatility and diversity" (Kemper, 2008).

Along with these differences, Yasaviya and Naqshbandiyya brotherhoods have common concept of strict asceticism. In his poetic works M. Koly, underlining temporality of secular life and the need to curb the instincts (Hikmet, 1, 2, 3) (Boryngy, 1964), advocates the idea of asceticism. Tatar poet Abdarrahima al-Bulgari (Utyz Imyani) raises the problem of ascetic values significance for a Sufi.

In his treatise Al-Saif is-Sarim, he emphasizes: "You should remember that asceticism in this world is an absolute measure of halts for the one who keeps the [Sufi] path. Ascetisim is the consequence of failing to follow the actions pleasant only for a soul"(Kemper, 2008).

The cult of poverty, specific to Sufis, is of fundamental importance in the formation of a unique Tatar people worldview and their culture. One of the ideologists of Sufism Al Ghazali, who defined the mystical love for God as the pinnacle of spiritual perfection of a man, asserts that "loving God, the Sufi should strive to renounce all mundane things" (Ishmukhametov, 1979).

It can be assumed that Al Ghazali's theory, in accordance with which Tatar Sufi literature of Middle Ages developed, had an impact on the evolution of hand-written book art. Sufism, which became the spiritual component of the society, brought up certain traits of character, especially such as the rejection of everything which is vulgar, excessively bright, the advantage of poverty over wealth, which is determined by the term "asceticism." We suppose that the concept of asceticism has fundamental significance for the development of the Tatar hand-written book design. Approaching a book as a holistic integral composition consisting of a binding, a book block, which in turn includes a frontispiece, a title page, the pages of the book, we can say that it was formed under the influence of Sufism. For example, the concept of asceticism led to omission of the pictorial elements. In addition, Tatar book binding has no embossing ornamentation, very specific to the book culture of the Arab-Muslim world.

Only in the middle of the $19^{\text {th }}$ century, when the religious and philosophical views were dominated not by Sufism, popular for centuries in the Volga region, but new reformatory ideas which appeared during that period, and what is especially important - there was the establishment of educational ideology and change of the book design: it 
now had a headpiece - unvan, decorated with flower-floral ornaments.

The oldest preserved Tatar manuscripts from the Kazan collections date back to the $17^{\text {th }}-18^{\text {th }}$ centuries. We cannot trace the design features of the manuscripts of earlier periods. But in the holdings of the National Archives and the National Museum of Kazan there are Kazan khans' yarlyks, diplomatic correspondence documents, which are the monuments of handwritten art. Visual analysis of the granted yarlyks of the Kazan Khans (a copy of the yarlyk of the Golden Horde Khan Ulug Mohammed to Turkish Sultan Murad Haas, 1428, National Archives of the Republic of Tatarstan; yarlyk of Khan Sahib-Giray, wielding the sceptre of the Kazan Khanate in 1521-24, The National Museum of the Republic of Tatarstan) shows that Kazan yarlyks are different from the similar documents of the same period but representing cultural monuments of the Crimean Khanate.

Crimean khans' yarlyks are characterized by the opulent design. The upper third of the yarlyk sheet had calligraphically written tugra of the Khan, which was supplemented with ornamental insertions. Crimean yarlyks had different color scheme, which is characterized by the use of a wide range of colors, the very tugra is usually executed in gold, ornamental insertions are finely drawn using different shades of blue, red. Compared to Crimean ones, Kazan khans' yarlyks are quite simple, there is only one color element - Khan's red stamp. Owing to that fact we assume that books copied by Tatar calligraphers in the Volga region in the $15^{\text {th }}, 16^{\text {th }}$ centuries are characterized by the same features, "they looked plain and modest" (Dmitriev, 1987).

According to the studied artifacts Tatar scribes attached great importance to color dealing with book page design. The books were rewritten on white paper using black ink to copy the basic text of the books. The red ink was used to highlight the essential fragments of the text. Specific words were highlighted using green ink. We assume that this particular color range was not accidental, and this phenomenon is explained by the fact that Sufism focuses on the mystical cognition of God. In Islamic mysticism, color has an important epistemological function, describing the state of mystic's soul, the degree of its purity (Vasiltsov, 2009).

In the mystical writings of famous Tatar Sufis Tajeddine Yalchigula and Nigmatulla Umar bin al-Utara it is mentioned that on the path of mysticism Sufi must commit oneself to remembering God's name. As an addition to the implications of mystical cognition the authors describe ten stages of dhikr (quiet remembrance of God's name). Each of them corresponds to a particular color and some part of a human body. The first five stages of dhikr are defined as "minor holiness" (Kemper, 2008). Sufi is able to distinguish each of these stages according to the color range (Kemper, 2008). The first substance is Heart, red color corresponds to it, the next stage is Spirit, which is denoted by white color (Vasiltsov, 2009). When the heart is purified, there comes red color and after cleansing of other substances white, green and black colors are revealed (Vasiltsov, 2009).

The study shows that one of the factors that influenced the formation of the Tatar handwritten book design in the $15^{\text {th }}$ - early $19^{\text {th }}$ centuries was specific features of Sufism ideology in the Volga region.

\section{Discussions}

The development of the Tatar religious and philosophical thought is reflected in the works of domestic scientists - R.M. Amirkhanov (1993), R.F. Muhametdinov (2000), T.K. Ibrahim, F.M. Sultanov \& A.N. Yuzeev (2002), A.N. Yuzeev $(2000,2001,2007)$, as well as in the research of the leading foreign scholars - Algara Hamida (1976), Allena J. Franka (1996), M.Kempera (2008), committed to studying the issues of Sufism in the Volga region.

Various aspects of the history of book art development in the Tatar culture are addressed by M.A. Usmanov $(1972,1979,1984,1994)$, where he gives grounds for the influence of Central Asian traditions on the formation of the Tatar book art. The genesis of the Tatar books is studied in the fundamental works of A.G. Karimullin (1969, 1974, 1989).

Since the beginning of the $20^{\text {th }}$ century the phenomenon of Tatar book has been studied by Russian art historians - P.M. Dulskij (1916, 1921, 1930), O.L. Ulemnova (2005) S.M. Chervonnaya (1978), R.I. Shamsutov (2001, 2003), who touched upon the issue of artistic design of a book to different extents. F.G. Vagapova's articles are dedicated to the analysis of artistic and imaginative features of the book (2012).

However, up to date the issues of the formation of handwritten book art in the culture of Tatars have not been addressed in the context of the Sufism ideology influence, in particular those of its forms, which it had acquired on the territory of the Volga region.

\section{Conclusion}

Proposed in the paper concept of a book as an integral composition, particular elements of which are formed under influence of specific factors revealed that the artistic and imaginative content of Tatar books was 
predetermined by the ideology of Sufism with its idea of asceticism and mystical cognition of God.

\section{Recommendations}

The results and findings of this study bring the understanding of the Tatar book phenomenon in the context of the culture of the Eurasian peoples to a new level. This perspective of the research can be applied to the development of specific educational courses: "History of culture and religion", "Culture and art of the peoples of Tatarstan", "History of World Culture."

\section{Acknowledgments}

The work is performed according to the Russian Government Program of Competitive Growth of Kazan Federal University.

\section{References}

Amirkhanov, R. M. (1993). Tatarskaya sotsialno-filosofskaya mysl srednevekovya. Kazan: Tatarskoye knizhnoye izdatelstvo.

Chervonnaya, S. M. (1978). Iskusstvo Sovetskoy Tatarii. Zhivopis. Skulptura. Grafika. Moskva: Izobrazitelnoye iskusstvo.

Dmitriyeva, L. V. (1989). Tyurkoyazychnaya arabopismennaya kniga i yeye arealy. In Akimushkin O. F. (Ed.), Rukopisnaya kniga v kulture narodov Vostoka (Kn.1, str. 407-450). Moskva: Nauka.

Dulskiy, P. M. (1916). Sovremennaya illyustratsiya v detskoy knige. Kazan.

Dulskiy, P. M. (1921). Kniga i yeye khudozhestvennaya vneshnost / v svyazi s kazanskim knigopechataniyem. Kazan: Bibliograficheskiy kruzhok «Druzey knigi».

Dulskiy, P. M. (1930). Oformleniye tatarskoy knigi za revolyutsionnyy period. Kazan: Tatpoligraf.

Frank, Allen J. (1996). Islamic Shrine Catalogues and Communal Geography in the Volga-Ural Region: 1788-1917. Journal of Islamic Studies, 265-286. http://dx.doi.org/10.1093/jis/7.2.265

Hamid, A. (1976). Silent and Vocal Dhikr in the Nagshbandi Order. VII Kongress für Arabistik und Islamwissenschaft: Proceedings Kongresses Gottingen 15. of the 1974 (pp. 39-46). Gettingen.

Ibragim, T. K., Sultanov, F. M., \& Yuzeyev, A. N. (2002). Tatarskaya religiozno-filosofskaya mysl $v$ obshchemusulmanskom kontekste. Kazan: Tatarskoye knizhnoye izdatelstvo.

Ishmukhametov, Z. A. (1979). Sotsialnaya rol i evolyutsiya islama v Tatarii. Kazan: Tatarskoye knizhnoye izdatelstvo.

Islam na yevropeyskom Vostoke. (2004). Nabiyev R.A. (Red.), Entsiklopedicheskiy slovar (str. 375, 262). Kazan: Magarif.

Kol Shərif. (1997). I kүңеl bu denyadyr... Gazallər, kyyssa (str. 25). Kazan: Tatar «Miras» kit. nəshr.

Mavlya Kolyy. Khikmet. (1964). 1, 2, 3. Gaynullin M.KH. (Red.), Boryngy tatar adabiyaty. (str. 488-489). Kazan: Tatar kitab nəshr.

Meier, F. (1994). Zwei Abhandlugen über die Nagšbandiyya. Stuttgart.

Mikhael, K. (2008). Sufii i uchenyye v Tatarstane i Bashkortostane. Islamskiy diskurs pod russkim gospodstvom (I.Gilyazov, per.). Kazan: Rossiyskiy islamskiy universitet.

Mukhametdinov, R. F. (2000). Sufizm v issledovaniyakh tatarskikh uchenykh. Sufizm v Povolzhye: Istoriya $i$ spetsifika. (str. 37-48.). Kazan: Iman.

Ocherki istorii tatarskoy obshchestvennoy mysli. (2000). Kazan: Tatarskoye knizhnoye izdatelstvo.

Shamsutov, R. I. (2001). Iskusstvo tatarskogo shamailya (ser. XIX-nach. XX vv.) Kazan: Reygent".

Shamsutov, S. I. (2003). Slovo i obraz v tatarskom shamaile ot proshlogo do nastoyashchego. Kazan: Tatarskoye knizhnoye izdatelstvo.

Ulemnova, O. L. (2005). Iskusstvo grafiki Tatarstana 1920-30-kh godov (Avtoreferat kandidatskoy dissertatsii). Kazan: Izdatelstvo Kazanskogo universiteta.

Usmanov, M. A. (1972). Tatarskiye istoricheskiye istochniki XVII - XVIII vekov. «Sbornik letopisey», "Daftar-i-Bulgariya», tatarskiye shadzhere. Kazan: Izdatelstvo kazanskogo universiteta.

Usmanov, M. A. (1979). Zhalovannyye akty Dzhuchiyeva Ulusa XIV - XVI vv. Kazan: Izdatelstvo kazanskogo 
universiteta.

Usmanov, M. A. (1984). Kauryy kaləm ezennən. Arkheograf yaemalary. Kazan: Tatar kitap nəshr.

Usmanov, M. A. (1994). Traditsii tatarskoy rukopisnoy knigi. Izmaylova R.U. (Sost.). Slovo o knige: Materialy nauchno-prakticheskoy konferentsii, posvyashchonnoy 270-letiyu tatarskoy pechatnoy knigi (str. 24-31). Kazan: Tatarskoye knizhnoye izdatelstvo.

Vagapova, F. G. (2012). Simvolika v oformlenii stranits drevney tatarskoy rukopisnoy knigi. In Sharafutdinov D. R. (Ed.), Ekho vekov (1-2, str. 28-35). Kazan.

Vagapova, F. G. (2012). Vidy i tipy ornamentov v oformlenii tatarskikh rukopisnykh knig (XVII - nachalo XX vv.). In Usmanova L. A. (Ed.), Filologiya i kultura. Philology and culture (3 (29), str. 168-172). Kazan: Izdatelstvo Kazanskogo universiteta.

Vasiltsov, K. S. (2009). Nekotoryye zamechaniya o simvolike i mifologii tsveta v musulmanskoy kulture. In Safar Abdullo (Ed.), Iran-Name. Nauchnyy Vostokovedcheskiy zhurnal (4 (12), str. 176-189). Almaty, Kazakhstan: Tsentr po izucheniyu kultury narodov Irana i Tsentralnoy Azii.

Yuzeyev, A. N. (2001). Tatarskaya filosofskaya mysl kontsa XVIII-XIX vv. Kazan: Tatarskoye knizhnoye izdatelstvo.

Yuzeyev, A. N. (2007) Filosofskaya mysl tatarskogo naroda. Kazan: Tatarskoye knizhnoye izdatelstvo.

\section{Copyrights}

Copyright for this article is retained by the author(s), with first publication rights granted to the journal.

This is an open-access article distributed under the terms and conditions of the Creative Commons Attribution license (http://creativecommons.org/licenses/by/3.0/). 